\title{
From Antipetismo to Generalized Antipartisanship: The Impact of Rejection of Political Parties on the 2018* Vote for Bolsonaro
}

\author{
Mario Fuks ${ }^{1}$ \\ https://orcid.org/0000-0003-2482-295X \\ Edinaldo Ribeiro ${ }^{2}$ \\ https://orcid.org/0000-0002-4005-5108 \\ Julian Borba ${ }^{3}$ \\ https://orcid.org/0000-0002-0149-6533
}

1Universidade Federal de Minas Gerais, Political Science Department, Belo Horizonte/MG, Brazil

2Universidade Estadual de Maringá, Social Sciences Department, Maringá/PR, Brazil

3Universidade Federal de Santa Catarina, Sociology and Political Science Department, Florianópolis/SC, Brazil

This article analyzes the effects of antipartisanship in explaining the Bolsonaro vote in the 2018 presidential elections. The expansion of the anti-Workers' Party sentiment known in Portuguese as 'antipetismo' into an antipartisanship that accommodates a wider range of targets and a growing association between antipartisanship and political intolerance provide the context for and underscore the relevance of our tests. Our expectation is that the vote for Bolsonaro was strong related to both antipetismo and negative attitudes towards mainstream political parties, especially when such attitudes were intense. The empirical basis of the present work was data from the Barometer of the Americas (LAPOP), particularly from the 2018/2019 wave. Empirical tests indicate that antipartisanship in its varied forms is a relevant phenomenon and had a major role in defining the electoral choices of 2018, particularly in the vote for Bolsonaro.

Keywords: Antipartisanship; political tolerance; electoral behavior; political attitudes.

http://doi.org/10.1590/1981-3821202100010003

For data replication, see: https://doi.org/10.7910/DVN/0LRFKG

Correspondence: Mario Fuks. E-mail: mariofuks@gmail.com

This publication is registered under a CC-BY Licence.

*The authors would like to thank CNPq and the Araucária Foundation for their financial support for the project that originated the article. 


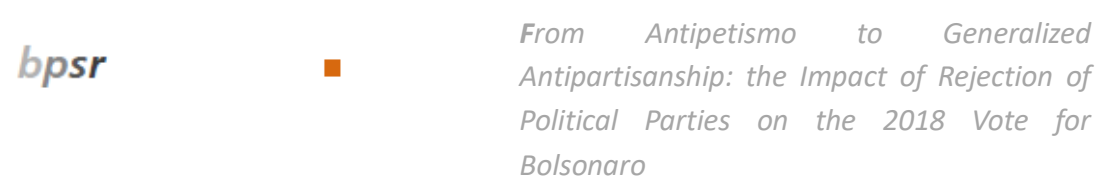

$1 \mathrm{n}$ issue of concern for researchers in the area of electoral behavior in Brazil is the vote for Bolsonaro in 2018. How can one explain the victory of a candidate with no public speaking skills, little name recognition, an incendiary discourse that made no concessions and a political party with few campaign funds and little media coverage? Bolsonaro's unexpected victory is usually explained by his appearance at an exceptional historical moment preceded by the 2013 protests, the impeachment of President Dilma Rousseff, the prosecution and imprisonment of the political leaders of the main political parties and an acute and prolonged economic crisis.

In this context, an increase in negative attitudes towards political institutions and elites is to be expected. This article focuses on these attitudes, specifically in relation to political parties. The 2018 election was the first since 1989 in relation to which it makes sense to inquire about the influence of the rejection of the main Brazilian political parties on the vote. Hence the question we intend to investigate: did antipartisan attitudes contribute to the vote for Bolsonaro? If so, was this merely a case of antipetismo or a wholesale rejection of the major political parties?

The main theoretical contribution of the article lies in our linking the literature on antipartisanship and studies on political tolerance, which leads to the development of a two-dimensional typology of antipartisanship. This typology takes into account not only the extent but also the intensity of voters' negative attitudes towards parties. The main empirical contributions of the article are: 01. presentation of evidence of the (unprecedented) impact of antipartisanship in the vote for Bolsonaro in 2018, well beyond that of antipetismo alone; 02. and demonstration that part of that antipartisan vote was also anti-system sentiment congruent with the political context and the option of an antiestablishment electoral alternative.

The article is divided into four sections. In the first, we present the theoretical debate on antipartisanship and voting and include contributions from the political tolerance agenda. The second section is dedicated to data and methodology. In the third section, we analyze longitudinally the picture of negative party feelings in the national context and then we present and discuss

(2021) $15(1) \quad$ - $\quad$ e0005-2/28 
our results from testing different types of antipartisanship and the 2018 elections. Finally, we return to the main findings of the study and suggest some directions for future research.

\section{Antipartisanship and Brazil}

Since at least the mid-1990s the concept of antipartisanship has been studied as a component of political dynamics (POGUNTKE, 1996; POGUNTKE and SCARROW, 1996). As a result, in the last twenty years, studies on electoral behavior have consolidated the view that parties are not only the axes of attraction for voters but also the objects of their rejection.

The literature is divided between the culturalist approach focusing on antisystem attitudes, their causes and consequences (POGUNTKE, 1996; POGUNTKE and SCARROW, 1996; TORCAL et al., 2002), and the study of partisanship, more specifically negative partisanship (ABRAMOWITZ and McKOY, 2019; ABRAMOWITZ and WEBSTER, 2016; MAYER, 2017; McGREGOR et al., 2015; MEDEIROS and NOËL, 2014).

The first approach considers the target of antipartisanship to be either the main parties that make up the current party system or the political parties per se (POGUNTKE, 1996). As a consequence, antipartisanship, especially that which rejects party associations in any circumstance, can contribute to the emergence of neopopulism, to a decline in support for a democratic regime and to patterns of antiestablishment behavior (MUDDE, 1996; SCHEDLER, 1996), especially in contexts characterized by the historical fragility of political parties, as is the case in Latin American countries (YERBA, 1998).

The second approach falls within the scope of studies of party identification and focuses on aversion to the party opposed to the party that the individual identifies with. In other words, identification with a party is complemented by the rejection of the party(ies) against which it competes (McGREGOR et al., 2015; MASON, 2018). A recent study by Abramowitz and Webster (2016) points out that negative partisanship is perhaps the most consistent political attitude of the American electorate today. An attitude held regardless of which party is identified or the strength of its identification, "American voters in the 21st century 


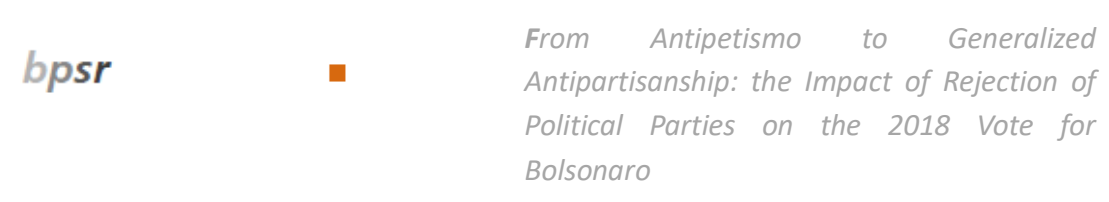

are much more likely to hold strongly negative views of the opposing party than in the past" (ABRAMOWITZ and WEBSTER, 2016, p. 21).

According to this view, the behavioral expression of negative partisanship is to not vote for the party that is the target of disaffection. Unsurprisingly, the principle method for measuring this phenomenon is by questioning interviewees about the party for which they would never vote (GARRY, 2007; MEDEIROS and NOEL, 2014; ROSE and MISHLER, 1998).

In Brazil, the topic of negative partisanship ${ }^{1}$ first went under the microscope in the studies carried out by Carreirão and Kinzo (2004) and Carreirão and Barbetta (2004), Carreirão (2008; 2007a; 2007b), Samuels (2008, 2006), Ribeiro, Carreirão and Borba (2016; 2011) and Neves (2012). These studies describe the negative feelings of Brazilians towards political parties as being of no lesser importance than their positive feelings, especially in the structuring of the vote.

When framing Brazilian negative partisanship within the scope of the international literature on antipartisanship, Samuels and Zucco (2018) concluded that the Workers' Party (PT) was the focus of almost all Brazilian voters' party sentiments, be they positive or negative. For Samuels and Zucco (2018), Brazilian antipartisanship is practically synonymous with antipetismo. As evidence of this, they cite the fact that in 2014, “[... $40 \%$ of voters were petistas [i.e. supporters of the PT] or antipetistas" and "[...] three quarters of antipartisans were antipetistas". (SAMUELS and ZUCCO, 2018, pp. 27-28).

Is antipartisanship in Brazil exclusively focused on the PT? In other words, is it synonymous with antipetismo? What Samuels and Zucco (2018) did not consider was the fact that a sizeable proportion of antipetistas also reject the other

\footnotetext{
${ }^{1}$ Considering the article's focus on antipartisanship, we chose to focus our review of the national literature on studies on negative partisanship. In addition to this discussion, it is worth mentioning the existence of a long tradition of studies on partisanship in its positive dimension. On that subject, we recommend Reis (1978) on the nature of partisanship in the context of the authoritarian regime; the study by Pereira (2014), which deals with the stability and effectiveness of party preference in the country. See also the study by Baker et al. (2016) on the dynamics of party identification in the recent period, and the study by Baker and Rennó (2019) which addresses the effects of different measures of partisanship on the levels of party identification in Brazil. A recent overview of the literature on partisanship in Brazil can be found in Fuks and Borba (2020, in press).
} 
main political parties. And, contrary to the argument of Samuels and Zucco, widespread antipartisanship has, at least in the case of 2018, "very precise implications" (SAMUELS and ZUCCO, 2018, p. 144) in terms of electoral choice.

We also argue that in addition to its scope, we must consider the intensity of antipartisanship. This intensity is higher when rejection of political parties is accompanied by political intolerance (POGUNTKE and SCARROW, 1996); that is, when the negative attitude is not restricted to disaffection, but also includes the desire to prevent parties from exercising their political activities.

Traditional political tolerance studies are restricted to radical groups. Influenced by the context of McCarthyism, Samuel Stouffer's pioneering study, 'Communism, Conformity and Civil Liberties' (1992 [1956]) explored attitudes of hostility and intolerance towards communists, atheists and socialists. The main source of longitudinal data on political tolerance in the USA, the 'General Social Survey', has, since the 1980s, included other groups that, according to the standards accepted by the majority of the population, behave in a deviant way, such as atheists, homosexuals, militarists and racists. While it has highlighted the increased number of targets of intolerance (GIBSON, 2008; SULLIVAN, PIERESON and MARCUS, 1982), recent literature has tended to maintain the focus on groups defending political positions perceived by the majority in society as extreme. This literature, therefore, does not take into account the fact that contexts of political crisis combined with political polarization may lead to intolerance of conventional groups as well, especially political parties ${ }^{2}$. This applies to Brazil today: the main parties of the Brazilian political system for 25 years (PT, PSDB and MDB), all of them conventional and moderate, have become the main targets of Brazilians' political intolerance (FUKS, RIBEIRO and BORBA, 2018).

In this article, we follow the same course as the studies by PAIVA, KRAUSE and LAMEIRÃO (2016) and FUKS, RIBEIRO and BORBA (2018), who argue that the rejection of other parties (besides the PT) has reached a level that obliges us to include it in any more careful analysis of Brazilians' partisan sentiments. Our argument is that while antipetismo continues to explain the vote in 2018 , overall rejection of the main political parties has become an equally relevant phenomenon.

\footnotetext{
${ }^{2}$ However, it must be considered that, at least in the case of the PT, it is possible that intolerance has some association with the party's positions in defense of political minorities.
}

(2021) $15(1) \quad$ - $00005-5 / 28$




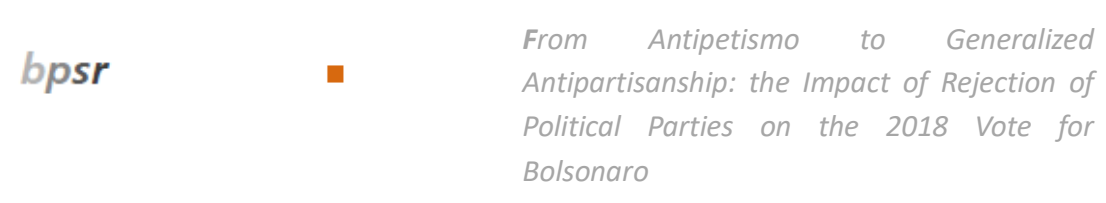

Thus, considering the theoretical debate and the political context presented above, we believe that it is necessary to expand the discussion on theories and typologies capable of explaining the various expressions of antipartisanship in Brazil. Studies that take a more culturalist line divide antipartisans between those who reject existing parties and those who adopt a general antipartisan stance, according to which parties are evil in themselves. In the tradition of studies on party identification, the pattern is to oppose two types of partisanship: positive and negative. In other words, in this second approach, there is no distinction between types of antipartisanship. Even models that intend to go beyond the binary typology do not escape this duality. In this tradition, Rose and Mishler (1998) present a more general typology of partisanship, but the negative partisan still boils down to one type: the voter who has no party identity and who would not, under any circumstances, vote for a particular party. The difference between the negative and positive partisan is that supporters identify themselves with a party whether or not they have negative identification with another party.

In order to fill the gaps, Fuks, Ribeiro and Borba (2018) constructed a typology that is based on the idea that antipartisanship is a bidimensional phenomenon and that, therefore, is only properly understood if we capture its variations in terms of disaffection to parties and of political tolerance.

The two variants of our typology, following the study mentioned above, distinguish voters according to the scope and intensity of their attitudes towards political parties, as can be seen in Table 01 and 02 .

In both cases, the typology divides up antipartisans according to intensity (tolerant or intolerant). The difference lies in the target and the extent of their rejection of the parties. In the first, disaffection and intolerance have two possible targets: the PT (restricted) and the three parties together (generalized). Thus, we have four profiles of antipartisan voters: the tolerant antipetista, the intolerant antipetista, the tolerant generalized antipartisan and the intolerant generalized antipartisan. The second variant of the typology does not target a specific party for disaffection. In this case, the factor that determines its scope is the number of parties: whether the target is one or two parties (restricted) or covers the three parties (generalized). So, again, we have four profiles of antipartisan 
voters: the tolerant restricted, the intolerant restricted, the tolerant generalized and the intolerant generalized.

Table 01. Typology A

\begin{tabular}{lll}
\hline $\begin{array}{l}\text { Scope } \\
\text { Intensity }\end{array}$ & Restricted & Generalized \\
\hline Tolerant & Tolerant antipetista & Generalized and tolerant antipartisan \\
Intolerant & Intolerant antipetista & Generalized and intolerant antipartisan
\end{tabular}

Source: Elaborated by the authors.

Table 02. Typology B

\begin{tabular}{lll}
\hline $\begin{array}{l}\text { Scope } \\
\text { Intensity }\end{array}$ & Restricted & Generalized \\
\hline Tolerant & Tolerant restricted antipartisan & Generalized and tolerant antipartisan \\
Intolerant & Intolerant restricted antipartisan & Generalized and intolerant antipartisan
\end{tabular}

Source: Elaborated by the authors

Our expectation is that antipetismo and generalized antipartisanship, especially the intolerant types, are more likely to vote for the 'anti-establishment' candidate Jair Bolsonaro than non-antipartisans (reference group). From this general proposition, we derive our two hypotheses:

H1: Antipetismo had an effect on the Bolsonaro vote in the 2018 elections, and that effect is even greater when accompanied by political intolerance.

H2: The rejection of all parties (generalized antipartisanship) had an effect on the vote for Bolsonaro, and this effect is even greater when accompanied by political intolerance.

Our hypotheses are based on the idea that, in an electoral context with a high rejection of the main political parties and with a candidacy that presents itself as an alternative to the conventional parties, both antipetismo and more general antipartisanship are important predictors of vote. In addition, this same context stimulates the more general and more intense types of antipartisanship, both of which have been given scant treatment in the Brazilian literature and both of which are important for helping explain the vote for Bolsonaro. 


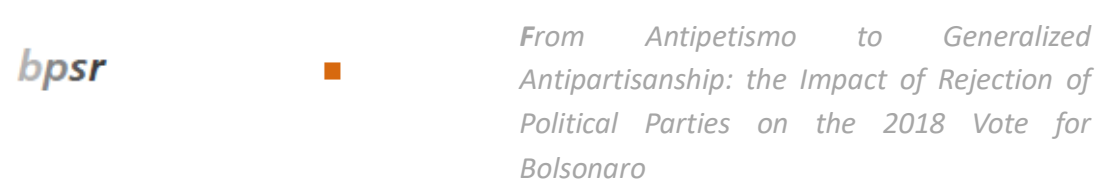

\section{Data and methodology}

By combining analysis of negative party feelings and political tolerance our study seeks to articulate, based on a typology, the scope and intensity of the rejection of parties by Brazilian voters.

Our primary source is the Barometer of the Americas 2018-2019, produced by the Latin American Public Opinion Project (LAPOP), based at Vanderbilt University 3 . Additionally, in an effort to develop a longitudinal perspective, we drew on the 2002, 2006, 2010 and 2014 waves of the Brazilian Electoral Study (ESEB), based at the Public Opinion Research Center of the University of Campinas (CESOPUNICAMP) 4 .

The 2019 edition of LAPOP asked questions about disaffection and political tolerance vis-à-vis the three main national parties. A first set of questions was designed to measure affection for these institutions and is worded as follows: "Speaking of political parties, how much do you like or dislike the following parties: (PT or PSDB or PMDB)? How much do you like or dislike them? (10 point response scale, with 01 meaning 'I don't like it at all' and 10 'I like it a lot')". The second set of questions adapts the traditional approach in studies on political tolerance (STOUFFER 1992; SULLIVAN, PIERESON and MARCUS, 1982; GIBSON, 2008) to radical groups to measure the interviewee's views regarding the right of parties to participate in elections. The LAPOP question is as follows: 'To what extent do you approve the right of (PT or PSDB or PMDB) to compete in the elections for president of Brazil? (10 point response scale, with 01 meaning 'totally disapprove' and 10 'totally approve')'.

From these two batteries of questions, we created eight disaffection profiles and eight tolerance profiles 5 . In the final stage, these profiles were combined into two variants of a typology that considers both the scope (disaffection) and the intensity (intolerance) of antipartisanship. In the first variant, the emphasis was on antipetismo, generating five groups: non-antipartisan, tolerant antipetista, tolerant

\footnotetext{
${ }^{3}<$ https://www.vanderbilt.edu/lapop/>.

${ }^{4}<$ https://www.cesop.unicamp.br/por/eseb>.

${ }^{5} \mathrm{An}$ empirical limit of the article is that the measurement of party disaffection was made considering only three parties (PMDB, PSDB and PT). The LAPOP battery considered only these parties, which until the 2018 elections, accounted for the vast majority of Brazil's electoral party preferences.
}

(2021) $15(1) \quad$ - $\quad 0005-8 / 28$ 
generalized antipartisan, intolerant antipetista and intolerant generalized antipartisan. The second variant, which does not take into account which party is the target of rejection, resulted in the following profiles: tolerant restricted antipartisan, tolerant generalized antipartisan, intolerant restricted antipartisan and intolerant generalized antipartisan.

To better characterize party disaffection in Brazil and its evolution over time, we use data from the 2002, 2006, 2010 and 2014 waves of the Brazilian Electoral Study (ESEB) and reproduced the same classification as that above.

For the empirical test of the effects of antipartisan types on voting in the 2018 presidential elections, we built two logistic regression models using Bolsonaro as a dependent variable. In both, the dependent variable is the vote for president, measured from the following question from LAPOP 2019: 'Who did you vote for to be president in the first round of the last election of 2018?'

The option to vote for Bolsonaro was tabulated as 1, and all other options as 0 . As independent variables, we use variant 1 of the antipartisan typology in the first model and, in the second model, variant 02 of the typology. The reference category in both is 'non-antipartisan'. In addition, we include as controls variables commonly used in studies on voting decision in Brazil (CARREIRÃO and RENNÓ, 2018), such as age, education, ethnicity, religion, ideological positioning and sociotropic assessment of the economy, in addition to two others that refer to topics that acquired particular relevance in the 2018 electoral debate: approval of samesex marriage and support for gun control deregulation. Details on these variables can be found in Annex A at the end of the article.

What differentiates the models, therefore, is the focus: 01 . in the first model, the focus is on antipetismo, compared to the rejection of all parties; 02 . in the second model, the focus falls on antipartisanship regardless of specific parties. All other independent variables are identical.

\section{Antipartisanship and vote for President in 2018}

Before presenting the results of the tests that weighed the importance of the various types of antipartisanship in explaining the 2018 vote, we present a longitudinal view of the negative sentiments towards the parties. Therefore, in addition to the 2019 data, we include here equivalent information 


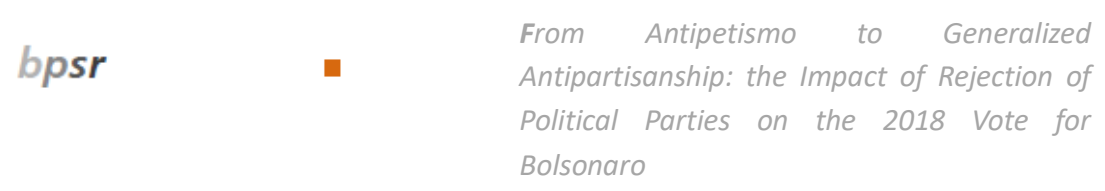

made available in a research series by the Brazilian Electoral Study (2002, 2006, 2010 and 2014). Table 03 makes it clear that the majority of the Brazilian electorate (58\%) rejected at least one party in 2019. It also verified that - just below the group that rejects the PT only (18.4\%) - lies the group that expresses disaffection to the set of parties (generalized) at $16.9 \%$.

Table 03. Groups by targets of disaffection, Brazil, 2002-2019

\begin{tabular}{lllllll}
\hline Group & 2002 & 2006 & 2010 & 2014 & 2018 & 2019 \\
\hline Not disaffected & 67.5 & 60.6 & 66.3 & 58.7 & 38.6 & 42.1 \\
Disaffected with the PT & 9.5 & 06 & 7.5 & 8.7 & 18.1 & 18.4 \\
Disaffected with the PSDB & 5.6 & 3.9 & 7.5 & 4.4 & 3.2 & 3.1 \\
Disaffected with the MDB & 1.2 & 1.29 & 2.6 & 2.6 & 3.1 & 2.3 \\
Disaffected with the PT and the PSDB & 5.1 & 0.8 & 01 & 01 & 06 & 5.7 \\
Disaffected with the PT and the MDB & 0.7 & 2.7 & 3.2 & 3.8 & 5.5 & 3.5 \\
Disaffected with the PSDB and the MDB & 6.9 & 10.1 & 6.6 & 07 & 8.8 & 7.9 \\
Generalized disaffection & 3.4 & 14.6 & 5.1 & 13.7 & 16.7 & 16.9 \\
N & 2394 & 943 & 1987 & 2376 & 1339 & 1443 \\
\hline
\end{tabular}

Sources: Elaborated by the authors based on Eseb (2020) (dates of 2018, 2014, 2010, 2006, 2002) and LAPOP (2019).

Note: Eseb scales from 0 to 10 ; Lapop scale 01 to 10 . The percentages refer to the initial points of the scales ( 0 or 01 ). The error margins (in \%) for each survey are, respectively: $02 ; 3.3 ; 2.2 ; 02 ; 2.2$; and 2.5 .

For the first time in the historical series, in 2019, the percentage of 'no disaffection' towards parties constitutes a minority in the Brazilian electorate, i.e., most Brazilian voters dislike one or more parties. It is apparent that those who express disaffection towards the PT only have been in the majority since 2002, with percentages that were relatively stable until 2014 (a minimum of $6 \%$ in 2006 and a maximum of $8.7 \%$ in 2014) and increased significantly in 2019 (18.4\%). On the other hand, disaffection for the other two parties, PSDB and PMDB, remain relatively stable throughout the period. And here is an important datum: those who do not like two or more parties, which was 9.9\% in 2002 (sum of disaffection towards the PT and PSDB; towards the PT and PMDB; towards PSDB and PMDB; and towards the set of parties), increased to 34\% in 2019. In other words, even though antipetismo is responsible for the largest share of party disaffection in Brazil, the phenomenon is much broader, affecting the set of political parties (the three parties analyzed here).

Graph 01, below, shows the distribution of respondents only among the proposed disaffection profiles, therefore, it does not consider the $42 \%$ of the sample 
classified as 'not disaffected'. In addition, we added all the profiles that combine rejection to two parties (lines 05, 06 and 07 in Table 03) in the 'mixed disaffection' category. This reveals the isolated 'leadership' of the PT (31.7\%), followed by the PMDB (9.9\%), with the PSDB being in the third position (5.4\%). Noteworthy, however, is the number of mixed respondents $(23.7 \%)$ and the number of respondents disaffected towards all three parties (29.2\%).

Graph 01. Party disaffection by party, Brazil, 2019 (\%)

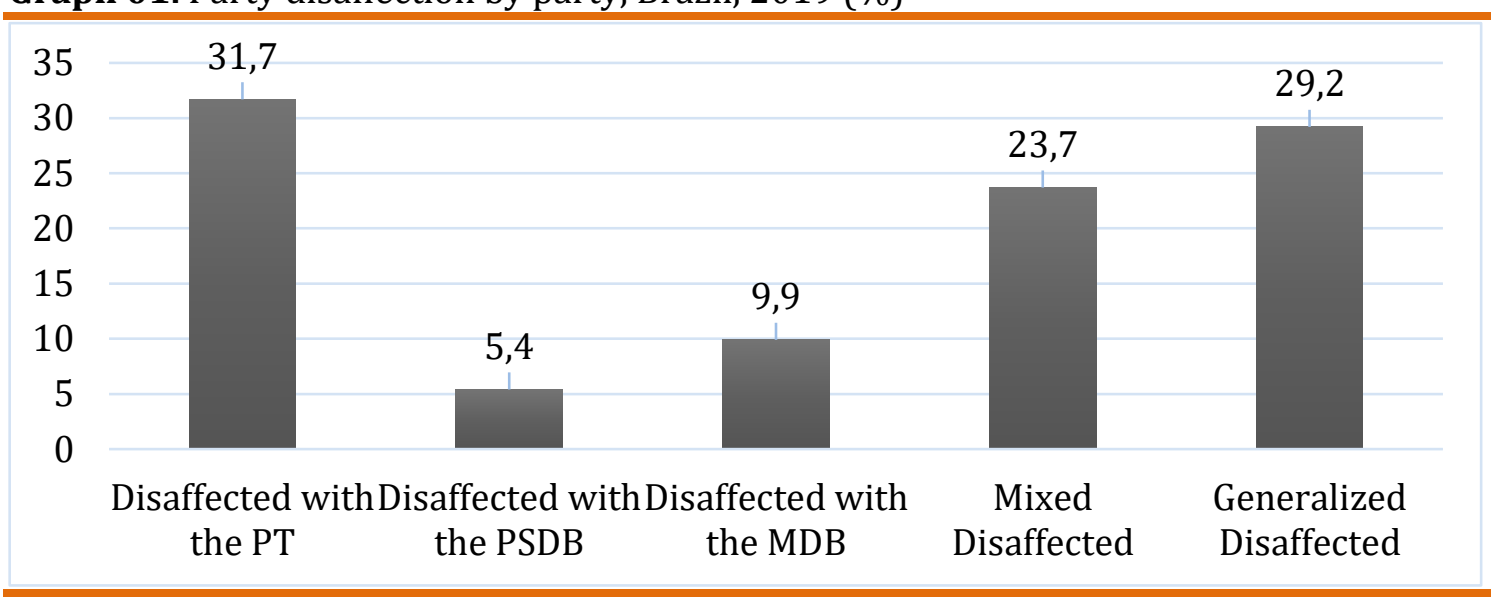

Source: Elaborated by the authors based on Lapop, 2019.

Notes: $\mathrm{N}=835$.

Turning to the data on political tolerance, for which we unfortunately only have information about 2019, Table 04 shows the distribution among eight groups, in which standouts those intolerant of the PT only (19.5\%), followed by those who express intolerance of all parties (11.2\%).

Graph 02 disregards the tolerant profiles, since the objective here is to present the distribution of the intolerant profiles. The three groups that are intolerant towards two parties were brought together into a single mixed category. Those intolerant of the PT only constitute the most significant group, totaling $41 \%$, but if we consider the mixed and generalized ones together we have a total of $46.7 \%$.

This set of information reveals the extent of rejection and intolerance of political parties in Brazil today. While almost 58\% of Brazilians express disaffection towards at least one party, $47.5 \%$ express intolerance. In other words, according to Lapop 2019, more than half of the population has negative attitudes towards 


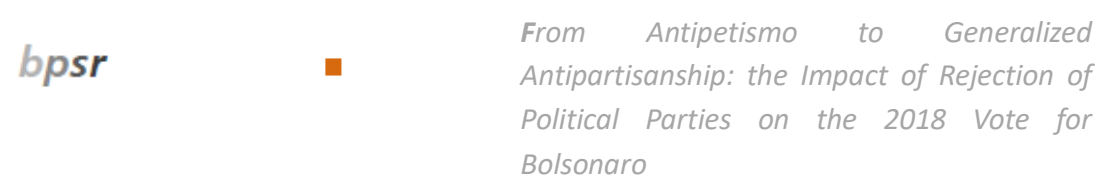

political parties and a large part of them translate this attitude into a denial of the right of those political parties to compete in presidential elections.

Graph 02. Political intolerance by party, Brazil, 2019 (\%)

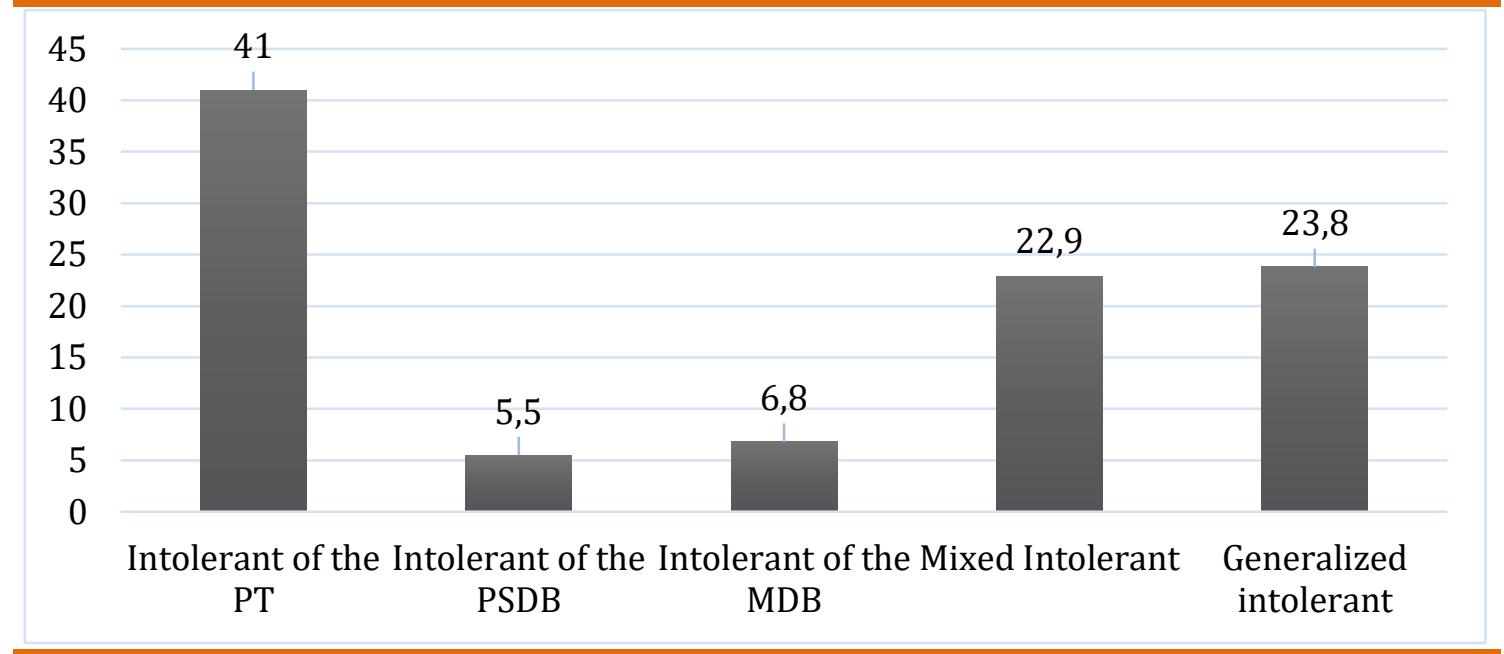

Source: Elaborated by the authors based on Lapop, 2019.

Notes: $\mathrm{N}=672$.

Table 04. Political intolerance groups, Brazil, 2019.

\begin{tabular}{lc} 
Group & $\%$ \\
\hline Generalized tolerant & 52.5 \\
Only intolerant of the PT & 19.5 \\
Only intolerant of the PSDB & 2.6 \\
Only intolerant of the PMDB & 3.3 \\
Intolerant of the PT and the PSDB & 2.5 \\
Intolerant of the PMDB and the PT & 4.2 \\
Intolerant of the PSDB and the PMDB & 4.2 \\
Intolerant generalized & 11.2 \\
$\mathrm{~N}$ & 1413 \\
\hline
\end{tabular}

Source: Elaborated by the authors based on Lapop, 2019.

Reinforcing evidence from previous studies (RIBEIRO, CARREIRÃO and BORBA, 2016; SAMUELS and ZUCCO, 2018), it is clear that rejection of the PT is a consolidated and widespread phenomenon, but that other parties are also targets for negative attitudes. In particular, a finding from the data is the existence of a more recent phenomenon, one that is just as noticeable as antipetismo: disaffection and generalized intolerance towards the entire set of parties. In other words, antipetismo coexists today alongside broader forms of antipartisanship. 
We established the PT as a reference party for the construction of the first variant of our typology. As our goal is to investigate antipartisanship, Graph 03 shows the percentage distribution of respondents in these groups, excluding nonantipartisans. Thus, considering only those who manifest party disaffection, there is a predominance $(39.5 \%)$ of intolerant antipetismo, i.e., of those who, in addition to rejecting the PT, also oppose the PT's right to launch candidacies in presidential elections. It is noteworthy, however, that one fifth of the sample defends the withdrawal of this political right for the three parties (generalized antipartisan), clearly configuring an anti-system posture.

Graph 03. Antipartisanship with an emphasis on antipetismo, Brazil, 2019 (\%)

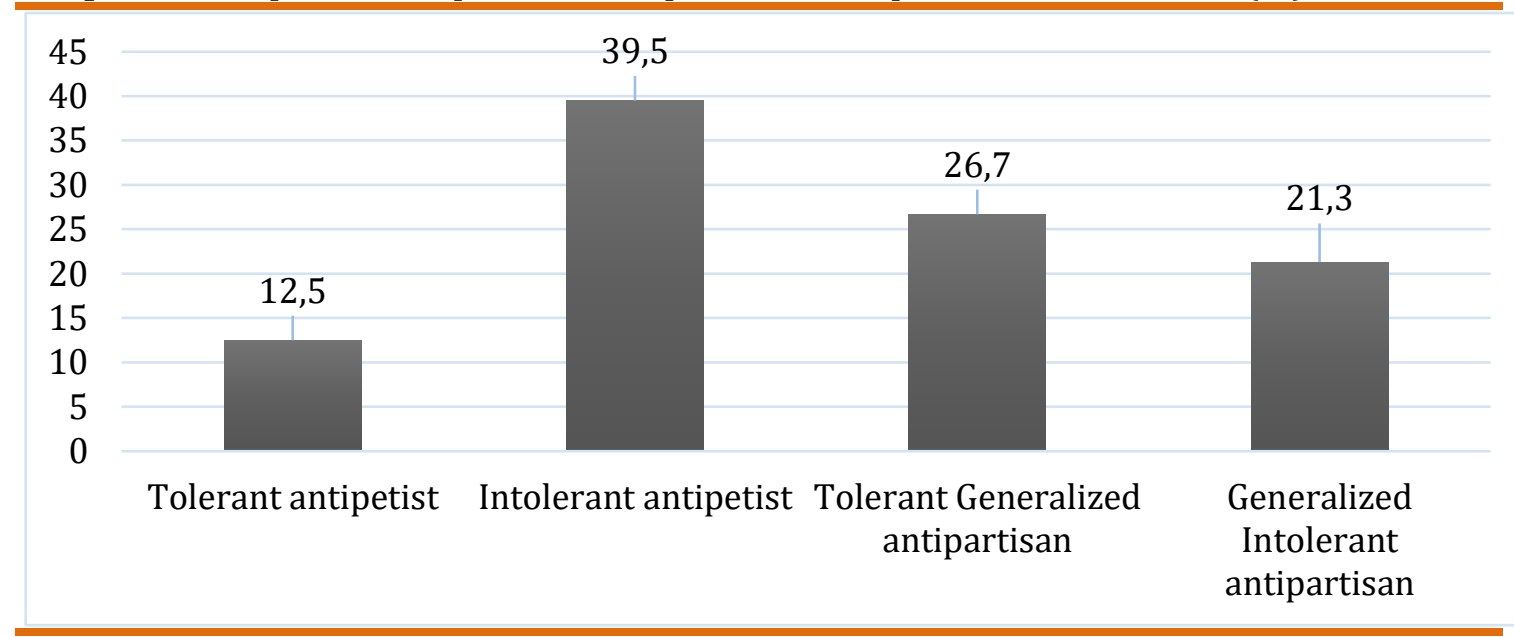

Source: Elaborated by the authors based on Lapop, 2019. Notes: $\mathrm{N}=489$.

By removing the PT from focus, we produced a second variant of the typology with the following profiles (Graph 04) that also disregarded nonantipartisan responses: tolerant restricted antipartisan (01 or 02 parties) (33.2\%); intolerant restricted antipartisan (6.7\%); generalized antipartisan but tolerant (47.1); finally intolerant generalized antipartisan (13\%).

The distribution of frequencies in both versions of the typology reiterates the pattern that we have already observed separately for disaffection and intolerance to parties: antipartisanship in today's Brazil is a broader phenomenon than antipetismo. 


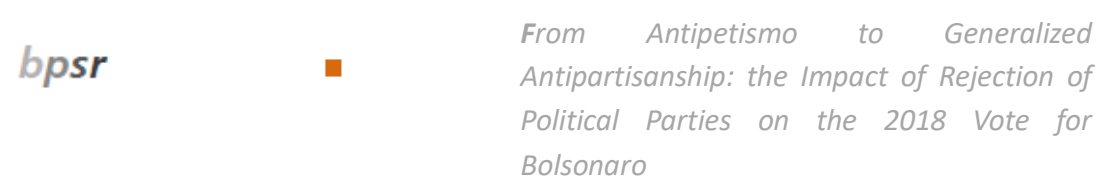

Graph 04. Antipartisanship with an emphasis on scope, Brazil, 2019 (\%)

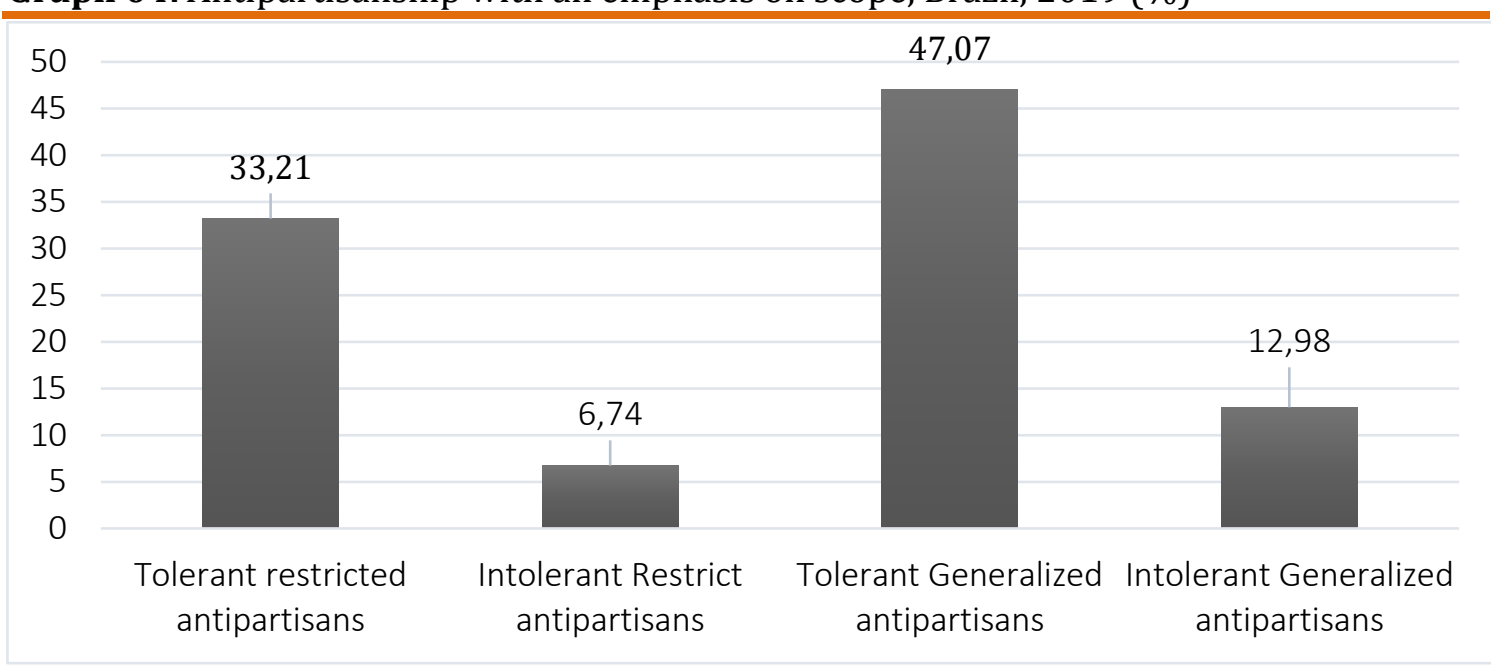

Source: Elaborated by the authors based on Lapop, 2019.

Notes: $\mathrm{N}=801$.

We will now see if the different types of antipartisanship had an effect on the Bolsonaro vote in 20186. In model 01 (Table 05), we tested our first hypothesis. The results show that, as in previous elections, several factors contributed to explain voters' choices in the last election? ${ }^{7}$. A positive evaluation of the economy had an effect on voting, raising the probability of a vote for Bolsonaro by $45 \%$ compared to the other candidates at each advance in the election on the three point scale ${ }^{8}$. As party bias (CAMPBELL et al., 1960) affects government appraisal, most likely preference or rejection of PT had an influence on interviewees' evaluation of how Temer handled the economy and voting for Bolsonaro.

Our data also confirm the expectation regarding the voting trends of certain groups in society. In comparison with other groups, whites ${ }^{9}$ are $46 \%$ more likely to

${ }^{6} \mathrm{An}$ alternative model was conducted by changing the cutoff points to create the initial measures of disaffection and intolerance. The extreme cut, originally at point 01 , was replaced by 03. The typology, considering these new cuts, produced similar effects, as can be seen in Table 02 of the annex, indicating considerable robustness of the procedure. Similar tests considering the tertiles of the measures of disaffection and tolerance are not feasible, since they are different between the three parties covered by the data in the two dimensions (disaffection and tolerance). The first tertiles range from 01 (in the case of PT in the measure of disaffection) to 03 (in the case of the PMDB in the measure of tolerance), i.e., all were covered by the cut used for this robustness test.

${ }^{7}$ Alternative multinomial models, considering the three main applications, can be consulted in Tables 03 and 04 of the annex.

${ }^{8}$ Question writing: Do you consider that the country's economic situation is better, equal or worse than 12 months ago? (worst $=0$, equal $=01$ and best $=02)($ LAPOP, 2019).

${ }^{9}$ Originally, the Lapop question comprised six categories (white, indigenous, black, mulatto, yellow and other). We recode the measurement to isolate whites and non-whites (white $=01$ and nonwhites $=0$ ). 
vote for Bolsonaro. In terms of formal education, each year of schooling increases the chance of voting for Bolsonaro by $5 \%$. This demonstrates that the structuring of Brazilian politics since at least 2006 around socio-demographic factors (SINGER, 2012) remained true in 2018, with those who opposed the PT having more chances among groups with higher income and education.

Table 05. Antipartisanship with an emphasis on antipetismo and the vote for Bolsonaro, Brazil, 2019

\begin{tabular}{|c|c|c|}
\hline & $\begin{array}{c}\text { B } \\
\text { (error) }\end{array}$ & $\operatorname{Exp}(B)$ \\
\hline Tolerant antipetista & $\begin{array}{c}1.032 * \\
(.433)\end{array}$ & 2.81 \\
\hline Intolerant antipetista & $\begin{array}{l}1.508^{* * *} \\
(.256)\end{array}$ & 4.52 \\
\hline Tolerant generalized antipartisan & $\begin{array}{l}0.792 * * \\
(0.273)\end{array}$ & 2.21 \\
\hline Intolerant generalized antipartisan & $\begin{array}{l}1.137 * * \\
(.364)\end{array}$ & 3.12 \\
\hline Sex (Female) & $\begin{array}{l}0.101 \\
(.174)\end{array}$ & 1.11 \\
\hline Age & $\begin{array}{l}0.007 \\
(.006)\end{array}$ & 1.01 \\
\hline Education & $\begin{array}{c}-0.046^{*} \\
(.024)\end{array}$ & 1.05 \\
\hline Ethnicity (White) & $\begin{array}{l}0.377^{*} \\
(.187)\end{array}$ & 1.46 \\
\hline Protestant Religion & $\begin{array}{c}0.572 * * \\
(.197)\end{array}$ & 1.77 \\
\hline Religion Other & $\begin{array}{l}-0.227 \\
(.241)\end{array}$ & 0.80 \\
\hline Atheist/Agnostic & $\begin{array}{l}-0.096 \\
(.650)\end{array}$ & 0.91 \\
\hline Centrist Ideological Positioning & $\begin{array}{l}0.294 \\
(.211)\end{array}$ & 1.34 \\
\hline Right-wing Ideological Positioning & $\begin{array}{c}1.046^{* * *} \\
(.230)\end{array}$ & 2.85 \\
\hline Approval of same-sex marriage & $\begin{array}{c}-0.051 * \\
(.024)\end{array}$ & 0.95 \\
\hline $\begin{array}{l}\text { Support for relaxation of arms } \\
\text { ownership regulations }\end{array}$ & $\begin{array}{l}0.896^{* * *} \\
(.170)\end{array}$ & 2.45 \\
\hline Sociotropic assessment of the economy & $\begin{array}{c}0.369 * * \\
(.118)\end{array}$ & 1.45 \\
\hline Constant & $\begin{array}{c}-2.114^{* * *} \\
(.484)\end{array}$ & 0.12 \\
\hline AIC & \multicolumn{2}{|c|}{942.78} \\
\hline $\mathrm{BIC}$ & \multicolumn{2}{|c|}{1023.269} \\
\hline Log Likelihood & \multicolumn{2}{|c|}{$-454,391$} \\
\hline $\mathrm{N}$ & \multicolumn{2}{|c|}{841} \\
\hline
\end{tabular}

Source: Elaborated by the authors based on Lapop, 2019.

Bolsonaro won support from significant segments of the Brazilian population by establishing alliances with religious leaders, especially evangelicals, 


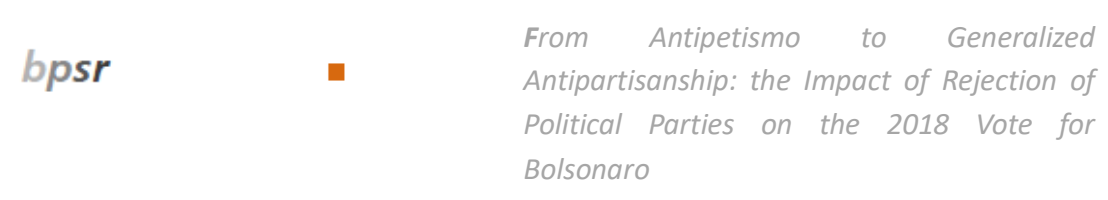

and taking unequivocal and vehement positions on issues such as sex education in schools, same-sex marriage, public security and threats from communism, and consistently affirmed the traditional family and religion as pillars of Brazilian society. The impact of values and religion on voting is confirmed in our model. Protestants ${ }^{10}$ are $77 \%$ more likely to vote for Bolsonaro than are Catholics. Even more striking is the increase in the probability of voting for Bolsonaro among those who express a desire to have a firearm ${ }^{11}-145 \%$. Consistently, attitudes favorable to same-sex marriage decreased the probability of voting for Bolsonaro by $5 \%$.

Ideology provides more evidence that attitudes played a decisive role in the 2018 election. It was unmistakably influential: voters who identified themselves as 'right-wing'12 were $185 \%$ more likely to vote for Bolsonaro. This link between ideology and voting in 2018 was strengthened by the campaigns, that repeatedly framed Bolsonaro as the most extreme rightwing candidate on the ballot. Centrist voters were more divided between candidates, as there was no statistically significant correlation between a centrist position and support for Bolsonaro.

Certainly, a broader study of the determinants of voting in 2018 would require a more detailed analysis of the role of all these factors. However, our concern here is to test the effect of antipartisan sentiments on the vote for Bolsonaro.

The first model shows that antipetismo was an excellent predictor of voting in 2018, especially in relation to the vote for Bolsonaro. Compared to 'nonantipartisan' voters, tolerant and intolerant antipetistas were more likely to vote for Bolsonaro, $181 \%$ and $352 \%$ respectively. It is important to note that the intensity of negative feeling towards a party matters, as apparent in respect to the differences between tolerant and intolerant voters. The same is true among generalized antipartisans although the difference in relation to the reference category is smaller. A tolerant generalized antipartisan has his or her probability of voting for Bolsonaro

\footnotetext{
${ }^{10}$ The categories listed by Lapop were: Catholic, Protestant, non-Christian Oriental religions, Evangelical, traditional, Spiritist, agnostic/atheist, none and other. We reduced for Catholics, Protestants (aggregates with evangelicals), others (aggregated with those who believe in a Higher Being but do not belong to any official religion) and atheists.

${ }^{11}$ The question asked by Lapop was: If you could, would you have a firearm for your protection? (yes $=01$, no $=0$ ).

${ }^{12}$ The question asked respondents to position themselves on a 10 -point scale, where 01 was equivalent to 'left' and 10 to 'right'. We recode this original measure by gathering points 01 to 03 as 'left', 04 to 07 as 'center' and 08 to 10 as 'right'.
}

$$
\text { (2021) } 15(1) \quad \text { - } \quad \text { e0005-16/28 }
$$


increased by $121 \%$, while the intolerant voters are $212 \%$ more likely to vote for Bolsonaro.

Additionally, we also estimated the predicted probabilities of each of these profiles, keeping all other variables stable (Table 06). We created archetypes with hypothetical individuals, all white, Catholic men with an average age of 39 years, an average of 09 years of education and positioned in the ideological center. Their average positioning in the scale of approval of marriage between people of the same sex is at point 05 , their approval of the relaxation of gun ownership laws is at point 4 and their assessment of the situation of the economy is 'stable' (neither worse nor better). The only characteristic that varies is their attitude towards the political parties, with the first being 'non-antipartisan', the second 'tolerant antipetista', the third 'intolerant antipetista', the fourth 'tolerant generalized' and the last 'intolerant generalized antipartisan'. The results shown in Table 06 reinforce the analysis presented above, highlighting the considerable differences between intolerance groups, especially among PT members, but also among the generalized ones.

Table 06. Predicted values for antipartisan profiles with an emphasis on antipetismo, Brazil, 2019

\begin{tabular}{lcccc} 
Non-antipartisan & $\begin{array}{c}\text { Tolerant } \\
\text { antipetista }\end{array}$ & $\begin{array}{c}\text { Intolerant } \\
\text { antipetista }\end{array}$ & $\begin{array}{c}\text { Tolerant } \\
\text { Generalized } \\
\text { antipartisan }\end{array}$ & $\begin{array}{c}\text { Intolerant } \\
\text { generalized } \\
\text { antipartisan }\end{array}$ \\
\hline Exp (B) & & & 3.47 & 3.81
\end{tabular}

Source: Elaborated by the authors based on Lapop, 2019.

These results only confirm the strong and consistent electoral impact of voters' attitudes towards the PT, whether positive or, in this case, negative. Petismo (i.e., pro-PT sentiment) and antipetismo are a distinct phenomenon and both are consistent indicators of the electoral behavior of Brazilians (RIBEIRO, CARREIRÃO and BORBA, 2016; SAMUELS, 2008; SAMUELS and ZUCCO, 2018). It was no different in 2018; antipetismo, especially in its intolerant expression, was one of the main predictors of the vote for Bolsonaro. Furthermore, in addition to antipetismo, negative attitudes towards the set of political parties examined here had a positive impact on the vote for Bolsonaro in 2018, especially among intolerant voters. This evidence confirms our first hypothesis. 


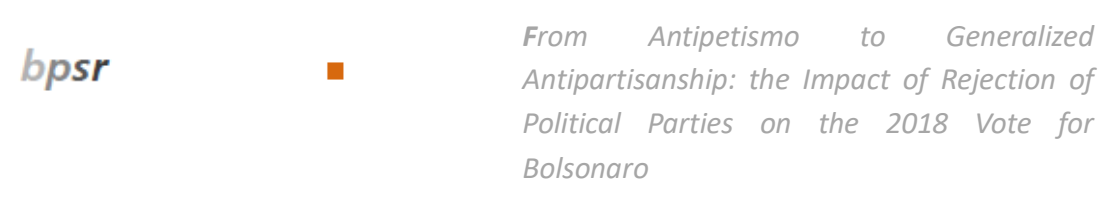

The results of the second model (Table 07), based on the typology that takes into account only the number of parties (without party distinction), test our second hypothesis. The results indicate, again, that antipartisanship had an influence on the vote. Compared to 'non-antipartisan' voters, restricted and generalized antipartisan voters are more likely to vote for Bolsonaro, but only when they are intolerant. While an intolerant restricted antipartisan has a 91\% greater chance of voting for Bolsonaro, for a intolerant generalized voter the increase is an impressive $171 \%$.

Therefore, the effect on voting in this second typology is conditioned by the intensity of the negative attitude towards the parties (intolerance), confirming our hypothesis about the vote for Bolsonaro as partially a result of a generalized disaffection towards political parties in Brazil, in addition to antipetismo. Although, in this second model, the effects of more comprehensive antipartisanship depend on the presence of intolerance, this result reinforces the relevance of our twodimensional typology and validates the emphasis on intolerance in our second hypothesis.

As we have done previously, we estimate the predicted probabilities of these profiles without party distinction. The hypothetical scenario exhibits the same demographic and attitudinal characteristics, but the distinction is now made between tolerant restricted antipartisan, intolerant restricted antipartisan, tolerant generalized antipartisan and intolerant generalized antipartisan. The results (Table 08) only reinforce our previous findings that voters who express both party disaffection and political intolerance were more likely to vote Bolsonaro.

The results presented above show the electoral impacts of a context in which politicians, political institutions, parties and everything related to politics loses the little appreciation it once enjoyed in society. With the offer of a candidate who represented such sentiments, dissatisfied voters found an electoral alternative to express their negative party identification. 
Table 07. Antipartisanship with emphasis on its scope and vote for Bolsonaro, Brazil, 2019

\begin{tabular}{|c|c|c|}
\hline & $\begin{array}{c}\mathrm{B} \\
\text { (error) }\end{array}$ & $\operatorname{Exp}(B)$ \\
\hline Tolerant restricted antipartisan ( 01 and 02 parties) & $\begin{array}{l}-0.012 \\
(.225)\end{array}$ & 0.99 \\
\hline Intolerant restricted antipartisan ( 01 and 02 parties) & $\begin{array}{c}0.648^{* * *} \\
(0.193)\end{array}$ & 1.91 \\
\hline Tolerant generalized antipartisan & $\begin{array}{l}0.151 \\
(.256)\end{array}$ & 1.16 \\
\hline Intolerant generalized antipartisan & $\begin{array}{c}0.998 * * \\
(.376)\end{array}$ & 2.71 \\
\hline Sex (Female) & $\begin{array}{l}0.057 \\
(.169)\end{array}$ & 1.06 \\
\hline Age & $\begin{array}{l}0.005 \\
(.006)\end{array}$ & 1.01 \\
\hline Education & $\begin{array}{c}-0.048^{*} \\
(.024)\end{array}$ & 1.05 \\
\hline Ethnicity (White) & $\begin{array}{l}0.403^{*} \\
(.183)\end{array}$ & 1.50 \\
\hline Protestant Religion & $\begin{array}{c}0.526^{* *} \\
(.194)\end{array}$ & 1.69 \\
\hline Religion Other & $\begin{array}{l}-0.301 \\
(.235)\end{array}$ & 0.74 \\
\hline Atheist/Agnostic & $\begin{array}{l}-0.018 \\
(.621)\end{array}$ & 0.98 \\
\hline Centrist Ideological Positioning & $\begin{array}{l}0.362 \\
(.208)\end{array}$ & 1.44 \\
\hline Right-wing Ideological Positioning & $\begin{array}{c}1.155^{* * *} \\
(.225)\end{array}$ & 3.17 \\
\hline Approval of same-sex marriage & $\begin{array}{l}-0.054 * \\
(.024)\end{array}$ & 0.95 \\
\hline Support for relaxed gun ownership regulations & $\begin{array}{c}0.913^{* * *} \\
(.167)\end{array}$ & 2.49 \\
\hline Sociotropic assessment of the economy & $\begin{array}{c}0.441^{* * *} \\
(.115)\end{array}$ & 1.55 \\
\hline Constant & $\begin{array}{c}-1.974 * * * \\
(.487)\end{array}$ & 0.14 \\
\hline AIC & \multicolumn{2}{|c|}{976.09} \\
\hline BIC & \multicolumn{2}{|c|}{1056.582} \\
\hline Log Likelihood & \multicolumn{2}{|c|}{$-471,047$} \\
\hline
\end{tabular}

Source: Elaborated by the authors based on Lapop, 2019.

Notes: Reference categories: Religion $=$ Catholic/ideological positioning $=$ left.

Table 08. Predicted values for antipartisan profiles with emphasis on its scope, Brazil, 2019

\begin{tabular}{lcccc}
\hline Non-Antipartisan & $\begin{array}{c}\text { Restricted } \\
\text { antipartisan (01 } \\
\text { and 02 parties) } \\
\text { tolerant }\end{array}$ & $\begin{array}{c}\text { Restricted } \\
\text { antipartisan (01 } \\
\text { and 02 parties) } \\
\text { intolerant }\end{array}$ & $\begin{array}{c}\text { Tolerant } \\
\text { generalized } \\
\text { antipartisan }\end{array}$ & $\begin{array}{c}\text { Intolerant } \\
\text { generalized } \\
\text { antipartisan }\end{array}$ \\
\hline Exp (B) & \multicolumn{5}{l}{3.54} & 3.89 \\
\hline 2.89 & 2.88 & 3.05 & 3.54 \\
\hline
\end{tabular}

Source: Elaborated by the authors based on Lapop, 2019. 


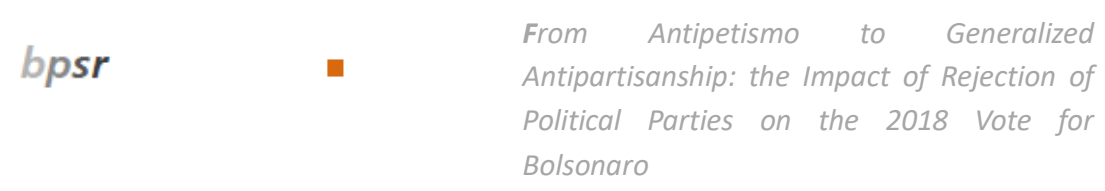

This scenario allows us to understand the expansion and intensification of the antipartisan phenomenon in Brazil. In this study, we found empirical evidence of a much broader phenomenon than that presented in the main work on the topic (SAMUELS and ZUCCO, 2018), according to which antipartisanship in Brazil is synonymous with antipetismo. The evidence presented here indicates that antipartisanship goes far beyond antipetismo and that its widespread manifestation, in 2018, has the same electoral consequences as antipetismo.

In addition, the inclusion of a dimension that has not yet been explored in studies on antipartisanship, has allowed us to verify the intensity of negative attitudes towards parties. As seen above, party intolerance, whether directed at one party or all of them, provided an important attitudinal basis for the election of Bolsonaro.

\section{Final considerations}

As we saw in the introduction, the 2018 elections took place in a context of profound political and economic crisis, with a general discontent weighing on the political class, parties and other democratic institutions. The effects of Operation Lava Jato and the fact that they intensified an economic recession had a devastating effect on the party system that had been taking shape since 1988 (DUQUE and SMITH, 2019; NICOLAU, 2017).

As had happened in other parts of the world, one of the candidates employed a discourse that criticized traditional representative institutions and thereby won over a portion of the electorate dissatisfied with the status quo. The parties identified during the campaign as the main operators of an 'old politics' became the primary targets for attacks, reactivating and potentiating strong rejection and, in some segments, intolerance towards the PT and other traditional Brazilian political parties.

The results that we present throughout this article show that antipartisanship, in its various manifestations, is a relevant phenomenon that had a major role in defining the electoral choices of 2018. Focusing simultaneously on the extent and intensity of these negative feelings, through an unprecedented combination of agendas on partisanship and political tolerance, we demonstrate 
through two variants of our typology that the breadth and strength of antipartisanship today is considerable and goes beyond one-dimensional rejection of a specific party.

In addition, it remains to be seen whether, in Brazil, antipartisanship has an impact only on electoral behavior or whether it is related to a broader and more articulated set of political behaviors and attitudes.

Translated by Fraser Robinson

Submitted on August 15, 2019

Accepted on June 01, 2020

\section{References}

ABRAMOWITZ, Alan I. and McCOY, Jeniffer (2019), United States: racial resentment, negative partisanship and polarization in Trump's America. Annals of the American Academy of Political and Social Science. Vol. 681, № 01, pp. 137-156.

ABRAMOWITZ, Alan I. and WEBSTER, Steven W. (2018), Negative partisanship: why Americans dislike parties but behave like rabid partisans. Advances in Political Psychology. Vol. 39, № 01, pp. 119-135.

ABRAMOWITZ, Alan I. and WEBSTER, Steven W. (2016), The rise of negative partisanship and the nationalization of U.S. elections in the 21st Century. Electoral Studies. Vol. 41, pp. 12-22.

BAKER, Andy; AMES, Barry; SOKHEY, Anand E., and RENNÓ, Lucio R. (2016), The dynamics of partisan identification when party brands change: the case of the Workers Party in Brazil. The Journal of Politics. Vol. 78, № 01, pp. 197-213.

BAKER, Andy and RENNÓ, Lúcio R. (2019), Nonpartisans as false negatives: the mismeasurement of party identification in public opinion surveys. Journal of Politics. Vol. 81, № 03, pp. 906-922.

CAMPBELL, Angus; CONVERSE, Philip E.; MILLER, Warren E., and STOKES, Donald E. (1960), The American voter. New York, London: John Wiley. 576 pp..

CARREIRÃO, Yan de Souza (2008), Opiniões políticas e sentimentos partidários dos eleitores brasileiros. Opinião Pública. Vol. 14, № 02, pp. 319-351.

CARREIRÃO, Yan de Souza (2007a), Relevant factors for the voting decision in the 2002 presidential election: an analysis of the Eseb (Brazilian Electoral Study) data. Brazilian Politic Science Review. Vol. 01, № 01, pp. 70-101.

CARREIRÃO, Yan de Souza (2007b), Identifição ideológica, partidos e voto na eleição presidencial de 2006. Opinião Pública. Vol. 13, № 02, pp. 307-339. 


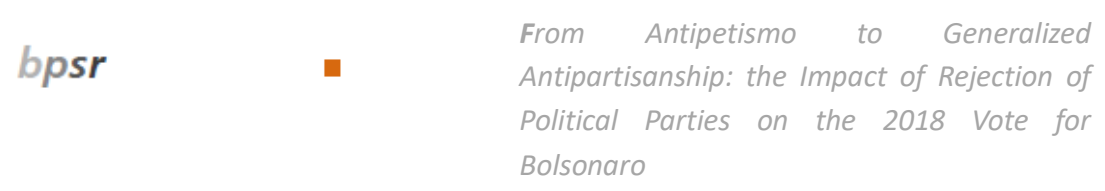

CARREIRÃO, Yan de Souza and BARBETTA, Pedro Alberto (2004), A eleição presidencial de 2002: a decisão e voto na região da Grande São Paulo. Revista Brasileira de Ciências Sociais. Vol. 19, № 56, pp. 75-93.

CARREIRÃO, Yan de Souza and KINZO, Maria D’Alva G. (2004), Partidos políticos, preferência partidária e decisão eleitoral no Brasil (1989/2002). Dados. Vol. 47, № 01, pp. 131-168.

CARREIRÃO, Yan de Souza and RENNÓ, Lucio R. (2018), Presidential voting: partisanship, economy and ideology. In: Routledge Handbook of Brazilian Politics. Edited by AMES, Barry. New York: Routledge. pp. 216-235.

DUQUE, Debora and SMITH, Amy Erica (2019), The establishment upside down: a year of change in Brazil. Revista de Ciencia Política. Vol. 39, № 02, pp. 165-189.

ESEB (2020), Brazilian Electoral Study. Available at <https://www.cesop.unicamp.br/por/eseb $>$. Accessed on February, 13, 2019.

FUKS, Mario and BORBA, Julian (2020), Sentimentos partidários: temas, controvérsias e sua recepção recente no Brasil. No prelo.

FUKS, Mario; RIBEIRO, Ednaldo, and BORBA, Julian (2018), Polarização, antipartidarismo e tolerância política no Brasil. Paper presented at Anais do $40^{\circ}$ Encontro Anual da Anpocs. São Paulo: Anpocs.

GARRY, John (2007), Making 'party identification' more versatile: operationalizing the concept for the multiparty setting. Electoral Studies. Vol. 26, № 02, pp. 346358.

GIBSON, James L. (2008), Intolerance and political repression in the United States: a half century after McCarthysm. American Journal of Political Science. Vol. 52, № 01, pp. 96-108.

LAPOP (2019), Latin American Public Opinion Project. Available at $<$ https://www.vanderbilt.edu/lapop $>$. Accessed on February, 10, 2019.

MASON, Lilliana (2018), Uncivil agreement: how politics became our identity. Chicago: University of Chicago Press. 192 pp..

MAYER, Sabrina (2017), How negative partisanship affects voting behavior in Europe: evidence from an analysis of 17 European multi-party systems with proportional voting. Research and Politics. Vol. 04, № 01, pp. 01-07.

McGREGOR, R. Michael; CARUANA, Nicholas J., and STEPHENSON, Laura B. (2015), Negative partisanship in a multi-party system: the case of Canada. Journal of Elections, Public Opinion and Parties. Vol. 25, № 03, pp. 300-316. 
MEDEIROS, Mike and NÖEL, Alain (2014), The forgotten side of partisanship: negative party identification in four Anglo-American democracies. Comparative Political Studies. Vol. 47, № 07, pp. 1022-1046.

MUDDE, Cas (1996), The paradox of the antipartisan party: insights from the extreme right. Party Politics. Vol. 02, № 02, pp. 265-276.

NEVES, Lucas Souza (2012), Preferência partidária na perspectiva do eleitorado brasileiro: mudanças e perpetuidades após as eleições presidenciais de 2002. Monografia. Bacharelado em Ciência Política. Universidade de Brasília.

NICOLAU, Jairo (2017), Os quatro fundamentos da competição política no Brasil (1994-2014), Journal of Democracy em Português. Vol. 06, № 01, pp. 83-106.

PAIVA, Denise; KRAUSE, Silvana, and LAMEIRÃO, Adriana Paz (2016), O eleitor antipetista: partidarismo e avaliação retrospectiva. Opinião Pública. Vol. 22, № 03, pp. 638-674.

PEREIRA, Frederico Batista (2014), A estabilidade e a efetividade da preferência partidária no Brasil. Revista Brasileira de Ciência Política. № 13, pp. 213-244.

POGUNTKE, Thomas (1996), Antipartisan sentiment: conceptual thoughts and empirical evidence: explorations into a minefield. European Journal of Political Research. Vol 29, № 03, pp. 319-344.

POGUNTKE, Thomas and SCARROW, Susan (1996), The politics of antipartisan sentiment: introduction. European Journal of Political Research. Vol. 29, № 03, pp. 257-262.

REIS, Fábio Wanderley (ed) (1978), Os partidos e o regime: a lógica do processo eleitoral brasileiro. São Paulo: Ed. Símbolo. 161 p..

RIBEIRO, Ednaldo; CARREIRÃO, Yan de Souza, and BORBA, Julian (2016), Sentimentos partidários e antipetismo: condicionantes e covariantes. Opinião Pública. Vol. 22, № 03, pp. 608-637.

RIBEIRO, Ednaldo; CARREIRÃO, Yan de Souza, and BORBA, Julian (2011), Sentimentos partidários e atitudes políticas entre brasileiros. Opinião Pública. Vol. 17, № 02, pp. 333-368.

ROSE, Richard and MISHLER, William (1998), Negative and positive party identification in post-communist countries. Electoral Studies. Vol. 17, № 02, pp. 217-234.

SAMUELS, David J. (2008), A evolução do petismo (2002-2008). Opinião Pública. Vol. 14 , № 02 , pp. 302-318. 


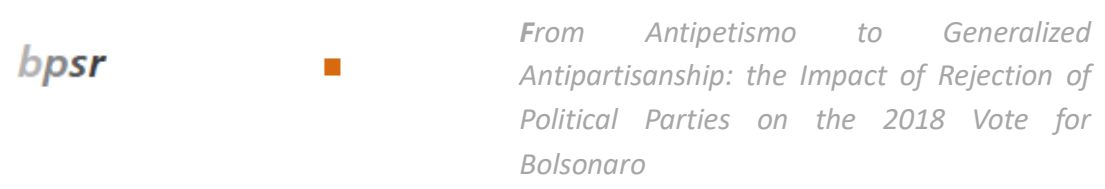

SAMUELS, David J. (2006), Sources of mass partisanship in Brazil. Latin American Politics and Society. Vol. 48, № 02, pp. 01-27.

SAMUELS, David J. and ZUCCO, Cesar (2018), Partisans, antipartisans, and nonpartisans: voting behavior in Brazil. Cambridge: Cambridge University Press. 196 pp..

SCHEDLER, Andreas (1996), Anti-political-establishment parties. Party Politics. Vol. 02, № 03, pp. 291-312.

SINGER, André (2012), Os sentidos do lulismo: reforma gradual e pacto conservador. São Paulo: Cia. das Letras. 276 pp..

STOUFFER, Samuel (1992), Communism, conformity and civil liberties: a new crosssection of the nation speaks its mind. New York: Routledge. 282 pp..

SULLIVAN, John L.; PIERESON, James, and MARCUS, George E. (1982), Political tolerance and American democracy. Chicago: University of Chicago Press. 288 pp..

TORCAL, Mariano; GUNTHER, Richard, and MONTERO, José (2002), Antipartisan sentiments in Southern Europe. In: Political parties: old concepts and new challenges. Edited by GUNTHER, Richard; LINZ, Juan J., and MONTERO, José Ramón. Oxford: Oxford University Press. pp. 257-290.

YEBRA, Covadonga Meseguer (1998), Sentimentos antipartidistas em el conosur: une studio exploratorio. América Latina Hoy. Vol. 18, pp. 99-112. 


\section{Annex}

Table 01. Sociodemographic descriptors by groups, Brazil, 2019

\begin{tabular}{lcccc}
\hline Group & $\begin{array}{c}\text { Gender } \\
\text { (\% Male) }\end{array}$ & $\begin{array}{c}\text { Education (Average } \\
\text { years completed) }\end{array}$ & $\begin{array}{c}\text { Age } \\
\text { (Average) }\end{array}$ & $\begin{array}{c}\text { Color } \\
\text { (\% White) }\end{array}$ \\
\hline Without disaffection & 47.4 & 8.9 & 37.9 & 23 \\
Disaffected with the PT & 50.6 & 9.1 & 40 & 37 \\
Disaffected with the PSDB & 40 & 8 & 42.7 & 22.7 \\
Disaffected with the MDB & 55.9 & 7.3 & 46.1 & 30.3 \\
Disaffected with the PT and the PSDB & 49.4 & 8.3 & 41.3 & 26.5 \\
Disaffected with the PT and the MDB & 60 & 09 & 41.7 & 38 \\
Disaffected with the PSDB and the & 48.4 & 8.7 & 36.6 & 21.2 \\
MDB & & & & \\
Generalized disaffection & 62.3 & 9.7 & 38.4 & 31.8 \\
\hline
\end{tabular}

Source: Elaborated by the authors based on Lapop, 2019.

Notes: Margin of error $2.5 \%$.

Table 02. Alternative model with cuts for antipartisans and intolerants at point 3 of the scale, with an emphasis on antipetismo

\begin{tabular}{|c|c|c|}
\hline & B (error) & $\operatorname{Exp}(B)$ \\
\hline Tolerant antipetista & $\begin{array}{c}0.886^{* *} \\
(.380)\end{array}$ & 2.42 \\
\hline Intolerant antipetista & $\begin{array}{c}1.545^{* * * *} \\
(.342)\end{array}$ & 4.68 \\
\hline Tolerant generalized antipartisan & $\begin{array}{c}1.023 * * \\
(.197)\end{array}$ & 2.78 \\
\hline Intolerant generalized antipartisan & $\begin{array}{c}1.105^{* *} \\
(.309)\end{array}$ & 3.01 \\
\hline Sex (Female) & $\begin{array}{l}0.099 \\
(.173)\end{array}$ & 1.10 \\
\hline Age & $\begin{array}{l}0.007 \\
(.006)\end{array}$ & 1.01 \\
\hline Education level & $\begin{array}{l}0.039 \\
(.024)\end{array}$ & 1.04 \\
\hline Ethnicity (White) & $\begin{array}{c}0.392 * * \\
(.186)\end{array}$ & 1.48 \\
\hline Protestant Religion & $\begin{array}{c}0.547^{* *} \\
(.198)\end{array}$ & 1.73 \\
\hline Religion Other & $\begin{array}{l}-0.300 \\
(.241)\end{array}$ & 0.74 \\
\hline Atheist/Agnostic & $\begin{array}{l}-0.211 \\
(.643)\end{array}$ & 0.81 \\
\hline Centrist Ideological Positioning & $\begin{array}{l}0.257 \\
(.211)\end{array}$ & 1.28 \\
\hline Right Ideological Positioning & $\begin{array}{c}1.077^{* * *} \\
(.229)\end{array}$ & 2.93 \\
\hline Approval of same-sex marriage & $\begin{array}{l}-0.053^{*} \\
(.025)\end{array}$ & 0.95 \\
\hline Support for relaxation of gun ownership regulations & $\begin{array}{c}0.842^{* * *} \\
(.170)\end{array}$ & 2.32 \\
\hline Sociotropic assessment of the economy & $\begin{array}{c}0.412 * * \\
(.118)\end{array}$ & 1.51 \\
\hline Constant & $\begin{array}{c}-2.127^{* * *} \\
(.484)\end{array}$ & 0.12 \\
\hline $\begin{array}{l}\mathrm{AIC} \\
\mathrm{N}\end{array}$ & \multicolumn{2}{|c|}{$\begin{array}{c}944.421 \\
840\end{array}$} \\
\hline
\end{tabular}

Source: Elaborated by the authors based on Lapop, 2019. 


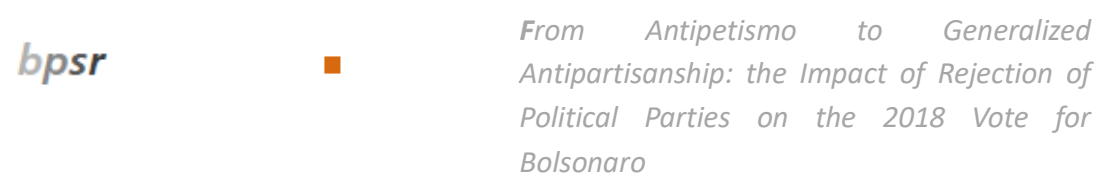

Table 03. Multinomial Models - Antipartisanship with an emphasis on antipetismo and voting, Brazil, 2019.

\begin{tabular}{|c|c|c|c|c|c|c|}
\hline & \multicolumn{2}{|c|}{ Haddad } & \multicolumn{2}{|c|}{ Ciro } & \multicolumn{2}{|c|}{ Others } \\
\hline & $\begin{array}{c}\text { B } \\
\text { (error) }\end{array}$ & $\operatorname{Exp}(B)$ & $\begin{array}{c}\text { B } \\
\text { (error) }\end{array}$ & $\operatorname{Exp}(B)$ & $\begin{array}{c}\text { B } \\
\text { (error) }\end{array}$ & $\operatorname{Exp}(B)$ \\
\hline Tolerant antipetista & $\begin{array}{c}-2.817^{* * *} \\
(1.048)\end{array}$ & 0.06 & $\begin{array}{l}-0.525 \\
(.801)\end{array}$ & & $\begin{array}{l}0.004 \\
(.506)\end{array}$ & \\
\hline Intolerant antipetista & $\begin{array}{l}-2.688^{* * *} \\
(0.479)\end{array}$ & 0.07 & $\begin{array}{l}-0.422 \\
(.459)\end{array}$ & & $\begin{array}{c}-0.764^{* *} \\
(.350)\end{array}$ & 0.46 \\
\hline $\begin{array}{l}\text { Tolerant generalized } \\
\text { antipartisan }\end{array}$ & $\begin{array}{c}-1.434^{* * *} \\
(.393)\end{array}$ & 0.24 & $\begin{array}{l}-0.690 \\
(.571)\end{array}$ & & $\begin{array}{l}0.022 \\
(.349)\end{array}$ & \\
\hline $\begin{array}{l}\text { Intolerant generalized } \\
\text { antipartisan }\end{array}$ & $\begin{array}{l}-2.595^{* * *} \\
(.753)\end{array}$ & 0.07 & $\begin{array}{l}-0.587 \\
(.670)\end{array}$ & & $\begin{array}{l}-0.157 \\
(.439)\end{array}$ & \\
\hline Sex (Female) & $\begin{array}{l}-0.120 \\
(.209)\end{array}$ & & $\begin{array}{l}0.542 \\
(.335)\end{array}$ & & $\begin{array}{l}-0.345 \\
(.244)\end{array}$ & \\
\hline Age & $\begin{array}{l}-0.010 \\
(.008)\end{array}$ & & $\begin{array}{l}-0.019 \\
(.013)\end{array}$ & & $\begin{array}{l}0.002 \\
(.009)\end{array}$ & \\
\hline Education level & $\begin{array}{c}-0.093^{* * *} \\
(.030)\end{array}$ & 0.91 & $\begin{array}{l}0.035 \\
(.048)\end{array}$ & & $\begin{array}{l}-0.007 \\
(.034)\end{array}$ & \\
\hline Ethnicity (White) & $\begin{array}{c}-0.514^{* *} \\
(.234)\end{array}$ & 0.60 & $\begin{array}{l}-0.107 \\
(.348)\end{array}$ & & $\begin{array}{l}-0.326 \\
(.264)\end{array}$ & \\
\hline Protestant Religion & $\begin{array}{c}-0.709^{* * *} \\
(.239)\end{array}$ & 0.49 & $\begin{array}{l}-0.952 * * \\
(.473)\end{array}$ & 0.40 & $\begin{array}{l}-0.233 \\
(.280)\end{array}$ & \\
\hline Other Religion & $\begin{array}{l}-0.111 \\
(.293)\end{array}$ & & $\begin{array}{c}0.931 * * \\
(.375)\end{array}$ & 2.54 & $\begin{array}{l}0.340 \\
(.324)\end{array}$ & \\
\hline Atheist/Agnostic & $\begin{array}{l}-0.454 \\
(.906)\end{array}$ & & $\begin{array}{l}0.518 \\
(.900)\end{array}$ & & $\begin{array}{l}0.272 \\
(.854)\end{array}$ & \\
\hline $\begin{array}{l}\text { Centrist Ideological } \\
\text { Positioning }\end{array}$ & $\begin{array}{c}-0.482 * * \\
(.241)\end{array}$ & 0.61 & $\begin{array}{l}-0.410 \\
(.384)\end{array}$ & & $\begin{array}{c}0.073 \\
(0.293)\end{array}$ & \\
\hline $\begin{array}{l}\text { Right-wing Ideological } \\
\text { Positioning }\end{array}$ & $\begin{array}{c}-1.217^{* * *} \\
(.277)\end{array}$ & 0.29 & $\begin{array}{c}-0.888^{* *} \\
(.450)\end{array}$ & 0.41 & $\begin{array}{c}-0.835^{* *} \\
(.341)\end{array}$ & 0.43 \\
\hline $\begin{array}{l}\text { Approval of same-sex } \\
\text { marriage }\end{array}$ & $\begin{array}{l}0.051^{*} \\
(.030)\end{array}$ & 1.05 & $\begin{array}{l}0.046 \\
(.050)\end{array}$ & & $\begin{array}{l}0.051 \\
(.035)\end{array}$ & \\
\hline $\begin{array}{l}\text { Support for relaxation of } \\
\text { gun ownership regulations }\end{array}$ & $\begin{array}{c}-0.757^{* * *} \\
(.209)\end{array}$ & 0.47 & $\begin{array}{c}-1.554^{* * *} \\
(.369)\end{array}$ & 0.21 & $\begin{array}{c}-0.856^{* * *} \\
(.245)\end{array}$ & 0.42 \\
\hline $\begin{array}{l}\text { Sociotropic assessment of } \\
\text { the economy }\end{array}$ & $\begin{array}{c}-0.414^{* * *} \\
(.144)\end{array}$ & 0.66 & $\begin{array}{l}-0.182 \\
(.233)\end{array}$ & & $\begin{array}{c}-0.384^{* *} \\
(.168)\end{array}$ & 0.68 \\
\hline Constant & $\begin{array}{c}2.458^{* * *} \\
(.577)\end{array}$ & & $\begin{array}{l}-0.841 \\
(.911)\end{array}$ & & $\begin{array}{l}-0.274 \\
(.684)\end{array}$ & \\
\hline $\begin{array}{l}\mathrm{AIC} \\
\mathrm{N}\end{array}$ & & & $\begin{array}{r}1628 \\
84\end{array}$ & & & \\
\hline
\end{tabular}

Source: Elaborated by the authors based on Lapop, 2019.

Notes: Reference categories: vote $=$ Bolsonaro; Antipartisan $=$ non-party; religion $=$ Catholic; ideological positioning $=$ left. 
Table 04. Multinomial Models - Antipartisanship with an emphasis on scope and voting, Brazil, 2019

\begin{tabular}{|c|c|c|c|c|c|c|}
\hline & \multicolumn{2}{|c|}{ Haddad } & \multicolumn{2}{|c|}{ Ciro } & \multicolumn{2}{|c|}{ Others } \\
\hline & $\begin{array}{c}\text { B } \\
\text { (error) }\end{array}$ & $\operatorname{Exp}(B)$ & $\begin{array}{c}\text { B } \\
\text { (error) }\end{array}$ & $\operatorname{Exp}(B)$ & $\begin{array}{c}\text { B } \\
\text { (error) }\end{array}$ & $\operatorname{Exp}(B)$ \\
\hline $\begin{array}{l}\text { Tolerant restricted } \\
\text { antipartisan (1 and } 2 \\
\text { parties) }\end{array}$ & $\begin{array}{l}-0.289 \\
(.264)\end{array}$ & & $\begin{array}{l}-0.233 \\
(.437)\end{array}$ & & $\begin{array}{c}0.622 * * \\
(.305)\end{array}$ & 1.86 \\
\hline $\begin{array}{l}\text { Intolerant Restricted } \\
\text { antipartisan (1 and } 2 \\
\text { parties) }\end{array}$ & $\begin{array}{c}-0.794^{* * *} \\
(0.228)\end{array}$ & 0.45 & $\begin{array}{l}-0.370 \\
(.376)\end{array}$ & & $\begin{array}{l}-0.478 \\
(.301)\end{array}$ & \\
\hline $\begin{array}{l}\text { Tolerant generalized } \\
\text { antipartisan }\end{array}$ & $\begin{array}{l}-0.536 \\
(.523)\end{array}$ & & $\begin{array}{l}-1.035 \\
(1.077)\end{array}$ & & $\begin{array}{l}0.672 \\
(.496)\end{array}$ & \\
\hline $\begin{array}{l}\text { Tolerant generalized } \\
\text { antipartisan }\end{array}$ & $\begin{array}{c}-2.489^{* * *} \\
(.763)\end{array}$ & 0.08 & $\begin{array}{l}-0.601 \\
(.684)\end{array}$ & & $\begin{array}{l}0.014 \\
(.456)\end{array}$ & \\
\hline Sex (Female) & $\begin{array}{l}-0.078 \\
(.200)\end{array}$ & & $\begin{array}{l}0.557^{*} \\
(.333)\end{array}$ & 1.74 & $\begin{array}{l}-0.310 \\
(.243)\end{array}$ & \\
\hline Age & $\begin{array}{l}-0.007 \\
(.007)\end{array}$ & & $\begin{array}{l}-0.018 \\
(.013)\end{array}$ & & $\begin{array}{l}0.004 \\
(.009)\end{array}$ & \\
\hline Education & $\begin{array}{c}-0.092^{* * *} \\
(.029)\end{array}$ & 0.91 & $\begin{array}{l}0.034 \\
(.048)\end{array}$ & & $\begin{array}{l}-0.005 \\
(.034)\end{array}$ & \\
\hline Ethnicity (White) & $\begin{array}{l}-0.545^{* *} \\
(.226)\end{array}$ & 0.58 & $\begin{array}{l}-0.111 \\
(.349)\end{array}$ & & $\begin{array}{l}-0.340 \\
(.265)\end{array}$ & \\
\hline Protestant Religion & $\begin{array}{c}-0.665^{* * *} \\
(.232)\end{array}$ & 0.51 & $\begin{array}{c}-0.929 * * \\
(.473)\end{array}$ & 0.39 & $\begin{array}{l}-0.156 \\
(.282)\end{array}$ & \\
\hline Other Religion & $\begin{array}{l}-0.005 \\
(.283)\end{array}$ & & $\begin{array}{c}0.953 * * \\
(.370)\end{array}$ & 2.59 & $\begin{array}{l}0.396 \\
(.325)\end{array}$ & \\
\hline Atheist/Agnostic & $\begin{array}{l}-0.467 \\
(.860)\end{array}$ & & $\begin{array}{l}0.539 \\
(.894)\end{array}$ & & $\begin{array}{l}0.203 \\
(.867)\end{array}$ & \\
\hline $\begin{array}{l}\text { Centrist Ideological } \\
\text { Positioning }\end{array}$ & $\begin{array}{c}-0.571^{* *} \\
(.235)\end{array}$ & 0.56 & $\begin{array}{l}-0.445 \\
(.386)\end{array}$ & & $\begin{array}{c}0.120 \\
(0.297)\end{array}$ & \\
\hline $\begin{array}{l}\text { Right-wing Ideological } \\
\text { Positioning }\end{array}$ & $\begin{array}{c}-1.346^{* * * *} \\
(.265)\end{array}$ & 0.26 & $\begin{array}{c}-0.914^{* *} \\
(.446)\end{array}$ & 0.40 & $\begin{array}{c}-0.836^{* *} \\
(.341)\end{array}$ & 0.43 \\
\hline $\begin{array}{l}\text { Approval of same-sex } \\
\text { marriage }\end{array}$ & $\begin{array}{c}0.059 * * \\
(.029)\end{array}$ & 1.06 & $\begin{array}{l}0.048 \\
(.050)\end{array}$ & & $\begin{array}{l}0.048 \\
(.035)\end{array}$ & \\
\hline $\begin{array}{l}\text { Support for relaxation of } \\
\text { arms ownership } \\
\text { regulations }\end{array}$ & $\begin{array}{c}-0.791^{* * *} \\
(.201)\end{array}$ & 0.45 & $\begin{array}{l}-1.509^{* * *} \\
(.369)\end{array}$ & 0.22 & $\begin{array}{l}-0.875^{* * *} \\
(.247)\end{array}$ & 0.42 \\
\hline $\begin{array}{l}\text { Sociotropic assessment of } \\
\text { the economy }\end{array}$ & $\begin{array}{c}-0.513^{* * *} \\
(.138)\end{array}$ & 0.60 & $\begin{array}{l}-0.206 \\
(.232)\end{array}$ & & $\begin{array}{c}-0.419^{* *} \\
(.168)\end{array}$ & 0.66 \\
\hline Constant & $\begin{array}{c}2.282^{* * *} \\
(.572)\end{array}$ & & $\begin{array}{l}-0.851 \\
(.927)\end{array}$ & & $\begin{array}{l}-0.613 \\
(.706)\end{array}$ & \\
\hline $\begin{array}{l}\text { AIC } \\
\mathrm{N}\end{array}$ & & & $\begin{array}{r}1683 . \\
84\end{array}$ & & & \\
\hline
\end{tabular}

Source: Elaborated by the authors based on Lapop, 2019.

Notes: Reference categories: vote = Bolsonaro; Antipartisan = non-party; religion = catholic; ideological positioning = left. 


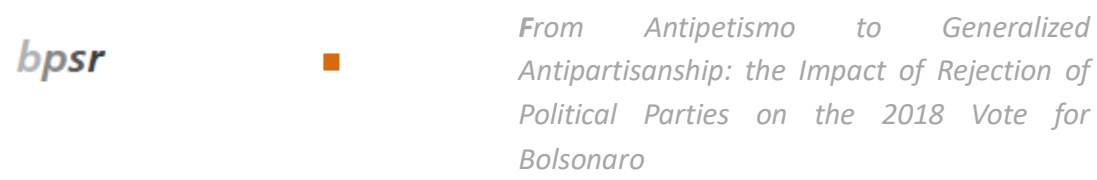

Chart 01. Questions and coding of the control variables in the regression models

\begin{tabular}{|c|c|c|c|}
\hline Variable & Question & Original coding & Recoding \\
\hline Age & How old are you? & Full years of life & Unnecessary \\
\hline Education & $\begin{array}{l}\text { How many years of schooling } \\
\text { have you completed? }\end{array}$ & $0-17$ or more & $\begin{array}{l}1=15 \text { years old or }+ \\
\text { (Tertiary) } \\
0=\text { less than } 15 \\
\text { years }\end{array}$ \\
\hline Ethnicity & $\begin{array}{l}\text { Do you consider yourself white, } \\
\text { mestizo, indigenous, black, } \\
\text { mixed race or other? }\end{array}$ & $\begin{array}{l}1=\text { White } \\
3=\text { Indigenous } \\
4=\text { Black } \\
5=\text { Mixed race } \\
7=\text { Other } \\
1506=\text { Yellow }\end{array}$ & $\begin{array}{l}1=1 \\
0=\text { Other categories }\end{array}$ \\
\hline Religion & $\begin{array}{l}\text { If you belong to any religion, } \\
\text { could you say which one? }\end{array}$ & $\begin{array}{l}1=\text { Catholic } \\
2=\text { Protestant } \\
3=\text { Non-Christian } \\
\text { oriental religion } \\
4=\text { None } \\
5=\text { Evangelical or } \\
\text { Pentecostal } \\
7=\text { Traditional } \\
\text { religion } \\
11=\text { Agnostic or } \\
\text { atheist } \\
77=\text { Other } \\
1501 \text { = Kardecist } \\
\text { Spiritist }\end{array}$ & $\begin{array}{l}1=1 \\
2=2 \text { and } 5 \\
3=3,4,7,77 \text { and } \\
1501 \\
4=11\end{array}$ \\
\hline $\begin{array}{l}\text { Ideological } \\
\text { positioning }\end{array}$ & $\begin{array}{l}\text { Changing the subject, on this } \\
\text { card we have a scale from } 1 \text { to } \\
10 \text { that goes from left to right, } \\
\text { where } 1 \text { means left and } 10 \\
\text { means right. Nowadays, when } \\
\text { talking about political trends, } \\
\text { many people talk about those } \\
\text { who sympathize more with the } \\
\text { left or the right. According to } \\
\text { the meaning that left and right } \\
\text { have for you when thinking } \\
\text { about politics, where would you } \\
\text { find yourself on that scale? Say } \\
\text { a number. }\end{array}$ & $\begin{array}{l}1=\text { Left } \\
10=\text { Right }\end{array}$ & Unnecessary \\
\hline $\begin{array}{l}\text { Evaluation of } \\
\text { the sociotropic } \\
\text { economy }\end{array}$ & $\begin{array}{l}\text { Do you consider that the } \\
\text { country's economic situation is } \\
\text { better, the same or worse than } \\
12 \text { months ago? }\end{array}$ & $\begin{array}{l}1=\text { Better } \\
2=\text { The same } \\
3=\text { Worse }\end{array}$ & $\begin{array}{l}0=3 \\
1=2 \\
2=1\end{array}$ \\
\hline $\begin{array}{l}\text { Approval of } \\
\text { same-sex } \\
\text { marriage }\end{array}$ & $\begin{array}{l}\text { To what extent do you approve } \\
\text { or disapprove of same-sex } \\
\text { couples having the right to } \\
\text { marry? }\end{array}$ & $\begin{array}{l}\text { 1=Totally } \\
\text { disapprove } \\
10=\text { Totally approve }\end{array}$ & Unnecessary \\
\hline $\begin{array}{l}\text { Support for } \\
\text { relaxation of } \\
\text { gun ownership } \\
\text { regulations }\end{array}$ & $\begin{array}{l}\text { If you could, would you have a } \\
\text { firearm for your protection? }\end{array}$ & $\begin{array}{l}1=\text { Yes } \\
2=\text { No }\end{array}$ & $\begin{array}{l}0=2 \\
1=1\end{array}$ \\
\hline
\end{tabular}

Source: Elaborated by the authors based on Lapop, 2019. 